\title{
NOTRE DAME DE PARIS, ROMANCE DRAMÁTICO?
}

\author{
Jefferson Cano
}

1

A maneira como a revista La muse française se apresentava aos seus leitores de $1823^{1}$, sintetizando algumas de suas ideias sobre literatura, ajuda-nos a situar o problema a ser discutido de início:

Embora as regras da arte sejam imutáveis como as leis da natureza, a fisionomia das literaturas variando com os séculos, a crítica deve necessariamente ter também a sua parte variável. Ela consiste em perceber e determinar as novas relações entre uma literatura que se modifica e o tipo eterno do belo. Ora, tendo a revolução francesa lançado a sociedade em caminhos desconhecidos e combinações sem exemplo, a literatura, que é a expressão da sociedade, se ressentiu profundamente desses violentos solavancos e dessas estranhas inovações. A crítica, por sistema ou por hábito, parece ter permanecido atrás do movimento geral. Daí resulta que ela não é sempre satisfatoriamente aplicável à literatura atual; pois para guiá-la ainda é preciso caminhar com ela (AVANT PROPOS..., 1823, p. 3-4).

Como declaração de princípios, o texto acabava revelando a tensão entre campos que o redator tentava aproximar. No mesmo movimento em que se busca separar mais claramente natureza e história, nota-se a dificuldade para definir-se em qual das esferas se encontrariam os atributos

${ }^{1}$ A revista foi fundada por Alexandre Soumet, Alexandre Guiraud, Émile Deschamps, Victor Hugo, Alfred de Vigny, Saint-Valry e G. Desjardins (SÉCHE, 1909). 
da arte. Sendo expressão da sociedade, a arte imergia na história, em seu movimento e suas variações; sendo expressão do belo, permanecia ligada a um ideal imutável. Mas a tensão não era exclusiva dos jovens editores da revista que estreava.

À mesma época, Stendhal publicaria uma série de artigos em tom de polêmica sob o título Racine e Shakespeare, nos quais se perguntava a qual dos dois autores seria preciso seguir para interessar ao público de 1823 (STENDHAL, 1823, p. 9). Ao contrapor os dois nomes, Stendhal contrapunha duas atitudes perante a arte, ambas possíveis a seus contemporâneos, e ainda duas atitudes perante o passado, que definiriam os campos opostos de clássicos e românticos:

O romanticismo é a arte de apresentar aos povos as obras literárias que, no estado atual de seus hábitos e de suas crenças, são suscetíveis de lhes dar o maior prazer possível. O classicismo, ao contrário, apresenta-lhes a literatura que dava o maior prazer possível a seus bisavôs. Sófocles e Eurípedes foram eminentemente românticos: deram aos gregos reunidos no teatro de Atenas tragédias que, segundo os hábitos morais desse povo, sua religião, seus preconceitos sobre o que faz a dignidade do homem, deviam procurar o maior prazer possível. Imitar hoje Sófocles e Eurípedes, e pretender que essas imitações não farão bocejar os franceses do século XIX, é classicismo (STENDHAL, 1823, p. 43).

Assim, a capacidade de atender ao gosto de seus contemporâneos era o que definia, para Stendhal, o romantismo, de modo que o que tornava Shakespeare um modelo para os românticos era justamente a sua capacidade de dar ao seu público o gênero de tragédia que esse apreciava e que não seria digno de entrar no teatro clássico do século de Luís XIV, assim como os "detalhes ingênuos [...] que tanto apreciamos hoje em dia em Ivanhoé e em Rob-Roy" (STENDHAL, 1823, p. 45). Os romances de Walter Scott serviam, em primeiro lugar, como referência do gosto do público, por ser reconhecido como "a obra literária de maior sucesso na França nos últimos dez anos”; mas, além disso, eles também expressariam, em sua contemporaneidade, um avanço sobre as tragédias ainda encenadas, uma vez que naqueles romances se encontraria o tipo da "tragédia romântica entremeada de longas descrições”. Dessa maneira, a renovação estética que se esperava para o teatro encontrava o seu modelo no romance, que forneceria uma fonte do "prazer dramático", enquanto as tragédias de modelo clássico só propiciavam um "prazer épico" por meio da declamação de belos versos (STENDHAL, 1823, p. 10). 
A importância da referência a Walter Scott para os homens de letras franceses daquele momento se reafirmava no lançamento de La muse française, cujo primeiro número trazia um artigo do jovem Victor Hugo sobre o romance Quentin Durward, de Scott, então traduzido na França. Segundo Hugo, o mérito do romancista estava em ter encontrado "nas fontes da natureza e da verdade um gênero desconhecido", reunindo aí "a minuciosa exatidão das crônicas, a majestosa grandeza da história e o interesse arrebatador do romance" (HUGO, 1823, p. 31). A novidade desse gênero vinha cumprir, aos olhos do jovem crítico, um papel histórico, atendendo à necessidade de uma geração que sucedia à Revolução Francesa e constituindo assim a literatura de uma nova era. Hugo comparava os períodos próximos à revolução com o estado de enfraquecimento que acometia os doentes antes e depois de acessos de febre. A sociedade doente exibia um gosto depravado, permitindo o triunfo de escritores ineptos "que estão hoje reduzidos a mendigar o aplauso dos lacaios e o riso das prostitutas". Superada essa fase doentia da sociedade, a consagração encontrada por Walter Scott tinha outra fonte:

Agora a popularidade não é mais distribuída pelo populacho: ela vem da única fonte que pode imprimir-lhe um caráter de imortalidade, e ao mesmo tempo de universalidade, do sufrágio desse pequeno número de espíritos delicados, de almas exaltadas e de cabeças sérias que representam moralmente os povos civilizados (HUGO, 1823, p. 33).

Era essa a popularidade que Scott obtivera ao buscar melhorar seu século e aperfeiçoar sua arte, aproximando-a da natureza, o que deveria ser o intento de todo romancista. Em primeiro lugar, tratava-se de "exprimir, em uma fábula interessante, uma verdade útil”; uma vez definida essa ideia fundamental, sua execução devia tornar o romance semelhante à vida, tomando por modelo a criação divina:

E a vida não é um drama bizarro, onde se misturam o bom e o mau, o bonito e o feio, o alto e o baixo, lei cujo poder só expira fora da criação? Será necessário, então, limitar-se a compor, como os flamengos, quadros inteiramente tenebrosos, ou, como os chineses, quadros totalmente luminosos, quando a natureza mostra, por toda parte, a luta entre a sombra e a luz? (HUGO, 1823, p. 34-35).

Hugo exaltava o papel inovador de Walter Scott, uma vez que até então a construção dependia de dois métodos contrários: ou em forma de narração, no qual "os personagens desapareciam, só o autor se mostra sempre", ou em forma de cartas, no qual "o autor se eclipsa para não deixar ver jamais senão os personagens"; ao primeiro faltaria a 
naturalidade do diálogo e da ação, enquanto que ao segundo faltariam as fórmulas polidas que se imitavam do gênero epistolar arrefecendo o retrato das paixões. Scott teria sido o responsável por superar esses métodos do romance narrativo e do romance epistolar, substituindo-os pelo romance dramático:

\begin{abstract}
[...] no qual a ação imaginária se desenrole em quadros verdadeiros e variados, como se desenrolam os eventos reais da vida; que não conheça outra divisão que a das diferentes cenas a desenvolver; que seja enfim um longo drama, no qual as descrições substituiriam as decorações e os costumes, os personagens poderiam se pintar por si mesmos e representar, por seus choques diversos e multiplicados, todas as formas da idéia única da obra. Encontrareis nesse gênero novo as vantagens reunidas dos dois gêneros antigos, sem os seus inconvenientes (HUGO, 1823, p. 37-38).
\end{abstract}

Mais uma vez, a leitura de Walter Scott servia para que se pensasse, no contexto francês, a renovação estética, pela aproximação entre drama e romance. Assim como Stendhal, Hugo recorria à ideia de drama para caracterizar o romance que ele via como pertencente a um gênero novo, inserindo-o no mesmo debate que já polarizava o campo literário entre clássicos e românticos e no qual o próprio Hugo se firmaria como figura de relevo ao publicar, poucos anos mais tarde, o seu drama Cromwell, precedido de um longo prefácio que constituiria um manifesto romântico, sem faltar-lhe inclusive o tom polêmico e combativo: "Há hoje o antigo regime literário como o antigo regime político. $O$ último século pesa quase inteiramente sobre o novo" (HUGO, 1828, p. LX).

Se Stendhal já distinguia o romântico do clássico por uma maior compreensão do primeiro de sua contemporaneidade, Victor Hugo levaria ao primeiro plano um sentido da história que enquadrava toda uma visão do desenvolvimento da humanidade, desde a sua infância até a velhice, o que ele dividia em "três grandes idades do mundo: nos tempos primitivos, nos tempos antigos, nos tempos modernos" (HUGO, 1828, p. IV). Como a cada tempo corresponderia uma arte própria, a poesia romântica, característica dos tempos modernos, se colocava ao fim de uma evolução da humanidade, superação necessária do classicismo.

Em sua reconstrução das idades do mundo, Hugo definia cada uma por um gênero poético característico. Assim, os tempos primitivos, quando toda a organização social baseava-se ainda em uma comunidade patriarcal, familiar, pastoril e nômade, caracterizavam-se pelo gênero lírico. Nos tempos antigos, o crescimento das famílias teria dado origem às cidades e ao poder político, sendo a comunidade patriarcal sucedida pela sociedade teocrática, pelos impérios e pelas guerras entre eles, 
mudança refletida na poesia, que se torna então épica; sendo a epopéia a expressão dessa civilização, o caráter épico assume diferentes formas, abrangendo também a história e a tragédia. Mais uma vez, o fim de uma civilização acompanhava o de sua forma poética: "Assim como a sociedade que ela representa, esta poesia se gasta girando sobre si mesma. Roma decalca a Grécia, Virgílio copia Homero" (HUGO, 1828, p. VII). Com isso, Hugo associava ao seu esboço de evolução histórica uma ideia de originalidade, dando-lhe um sentido também histórico: a decadência de um gênero se revelava quando ele passava a ser cópia. Se a cada idade correspondia um espírito próprio, a cópia de uma arte do passado desrespeitava a própria lei de evolução da história, sendo necessariamente um sinal de decadência.

Enfim, os tempos modernos seriam caracterizados pelo gênero dramático. Sua origem se encontrava no advento do cristianismo em um momento de revolução, catástrofe, ruína, convulsão, agonia do mundo antigo - uma profusão de termos com que Hugo mostrava o abalo nunca antes sofrido e que estaria na raiz de uma nova atitude perante a vida, marcada pela melancolia e pelo espírito de exame, uma vez que "o homem, voltando-se para si mesmo em presença dessas altas vicissitudes, começou a ter piedade da humanidade, a meditar sobre as amargas derrisões da vida" (HUGO, 1828, p. X). Mas o principal elemento que a estética hugoana encontraria no advento do cristianismo era a consciência de uma dualidade: o homem passava a ser um ponto de interseção entre duas vidas de que participava, a do corpo e da alma, a material e a imaterial, a terrena e a celeste, uma passageira e outra imortal (HUGO, 1828, p. VII). Tal separação dualista era uma das revoluções que o cristianismo engendrara no conceito de homem; enquanto a teogonia antiga era materialista, elevando o homem e humanizando as divindades, o cristianismo instaurava um abismo entre o homem e Deus (HUGO, 1828, p. IX).

A consciência dessa dualidade, para Hugo, seria a fonte da nova poesia, pois enquanto a poesia épica reduzia a natureza a uma única face, um único tipo de belo, a arte da era cristã se aproximava da verdade da natureza, revelando, portanto, a dualidade humana, misturando a sombra com a luz, o grotesco com o sublime, o corpo com a alma, o animal com o espírito. Na utilização do grotesco como um traço característico da poesia estaria a diferença fundamental que separava a arte moderna da antiga, a literatura romântica da clássica. Aí se encontraria "a mais rica fonte que a natureza pode abrir à arte”, oferecendo-lhe um meio de contraste, necessário para a melhor percepção do belo, pois "esta beleza universal que a Antiguidade espalhava solenemente sobre tudo não era 
sem monotonia; a mesma impressão, sempre repetida, pode fatigar com o tempo" (HUGO, 1828, p. XVI). Além disso, o contraste entre sublime e grotesco servia para representar a dualidade do homem, pois enquanto o sublime representaria a alma "tal qual é, purificada pela moral cristã", o grotesco representaria o papel da "besta humana" (HUGO, 1828, p. XVII). Enfim, Victor Hugo sintetizava as características que definiam cada época da história pela sua associação a uma poesia própria:

\footnotetext{
Os tempos primitivos são líricos, os tempos antigos são épicos, os tempos modernos são dramáticos. A ode canta a eternidade, a epopéia soleniza a história, o drama pinta a vida. O caráter da primeira é a ingenuidade, o caráter da segunda é a simplicidade, o caráter da terceira a verdade. [...] A ode vive do ideal, a epopéia do grandioso, o drama do real (HUGO, 1828, p. XX-XXI).
}

Assim, Hugo enfatizava em seu resumo a distinção da arte dos tempos modernos frente às formas do passado atribuindo a ela, e não a qualquer outra, a representação da vida, da verdade e do real. Mas essa verdade romântica, o nível de realismo aí atingido, construía-se em função dos contrastes, das antíteses, o que parecia se mostrar eficaz especialmente no momento de se contrapor à estética clássica, que se pautava pela separação de estilos. Ao contrário dessa, ao contrastar o grotesco e o sublime, Hugo concebia o real como a convivência desses pólos opostos, mas nunca a sua redução a um meio termo, a uma mediania. E essa "aliança íntima e criadora" do grotesco com o belo marcava de tal maneira o que ele chamava "terceira civilização" que "até as mais ingênuas lendas populares explicam, algumas vezes, com um admirável instinto, este mistério da arte moderna. A Antiguidade não teria feito A Bela e a Fera" (HUGO, 1828, p. XIX).

Sendo essa, então, a concepção de drama que explicava a civilização moderna para Victor Hugo, convém lembrar que a categoria de "romance dramático", que ele aplicava ao romance histórico de Walter Scott, embora anterior a essa definição, já continha seu elemento central, ao conceber a vida como um "drama bizarro, onde se misturam o bom e o mau, o bonito e o feio, o alto e o baixo" (HUGO, 1823, p. 34-35). Assim, o caminho percorrido até aqui nos leva a propor a leitura de Notre Dame de Paris a partir desses conceitos. Experimentado na escrita de romances, após ter já explorado o elemento grotesco em Han d'Islande e o histórico em Bug-Jargal, em 1827 Victor Hugo havia encontrado a formulação teórica que lhe permitia reunir os dois elementos em um todo coeso e necessário. Mas essa formulação, que ele apresentava no prefácio do Cromwell, não encontraria sua plena realização naquele drama, e sim no seu próximo romance (histórico ou 
dramático), que, talvez pretendendo dar voz ao que ele chamava instinto popular, reelaborava e oferecia em um quadro histórico a sua própria versão do encontro entre uma bela e uma fera.

A bela era Esmeralda, cigana perseguida pela Inquisição, e a fera Quasímodo, monstruoso sineiro da catedral de Notre Dame que a protege: essas figuras protagonizariam o trágico encontro na Paris do século XV que fornece a matéria ao romance. $\mathrm{O}$ contraste entre ambos é tão grande quanto o amor impossível que o corcunda nutre por Esmeralda. O primeiro a ser descrito será Quasímodo, por ocasião de uma festa de Reis em que ele será eleito o papa dos loucos, após vencer um concurso de caretas:

\begin{abstract}
Era, de fato, uma maravilhosa careta aquela que raiava agora no buraco da rosácea. Após todas as figuras pentagonais, hexagonais e heteróclitas que haviam se sucedido nessa janela sem realizar este ideal do grotesco que se construíra nas imaginações exaltadas pela orgia, não era necessário nada menos, para conquistar os votos, que a careta sublime que acabava de deslumbrar a assembleia. [...] A aclamação foi unânime; precipitaram-se para a capela. Fizeram sair dela em triunfo o bem-aventurado papa dos loucos. Mas foi então que a surpresa e a admiração chegaram ao cúmulo: a careta era seu rosto. Ou melhor, toda sua pessoa era uma careta. Uma grande cabeça eriçada de cabelos ruivos, entre os dois ombros, uma corcunda enorme cujo contragolpe se fazia sentir pela frente; um sistema de coxas e de pernas tão estranhamente desviadas que elas só podiam se tocar pelos joelhos e, vistas de frente, pareciam duas foices que se juntavam pelo cabo; grandes pés, mãos monstruosas; e, com toda esta deformidade, não sei que aspecto temível de vigor, de agilidade e de coragem; estranha exceção à regra que quer que a força, como a beleza, resulte da harmonia. Tal era o papa que os loucos acabavam de se dar. Dir-se-ia um gigante quebrado e mal soldado (HUGO, 1831, I, p. 102-104).
\end{abstract}

Ainda na mesma festa, a cena muda quando a atenção das personagens é desviada para a figura da cigana que apresentava seu número de dança na praça:

Ela não era alta, mas parecia, tanto seu fino talhe se lançava ousadamente. Ela era morena, mas se adivinhava que de dia sua pele devia ter esse belo reflexo dourado das andaluzas e das romanas. Seu pequeno pé também era andaluz, pois estava ao mesmo tempo apertado e à vontade em seu gracioso sapato. Ela dançava, ela dava voltas, ela turbilhonava sobre um velho tapete da Pérsia, jogado negligentemente sob seus pés; e, cada vez que, volteando, sua radiante 
figura passava diante de vós, seus grandes olhos negros vos lançavam um brilho. Em torno dela, todos os olhares estavam fixos, todas as bocas abertas; e, de fato, enquanto ela dançava assim, ao ruído do pandeiro que seus braços redondos e puros levantavam acima de sua cabeça, pequena, frágil e viva como uma vespa, com seu corpete de ouro sem dobras, o vestido colorido que se estufava, com seus ombros nus, suas pernas finas, que sua saia descobria por instantes, seus cabelos negros, seus olhos de fogo, era uma sobrenatural criatura (HUGO, 1831, I, p. 131-132).

Não somente as figuras são diferentes, mas também a técnica empregada em cada descrição. Enquanto Quasímodo é descrito em suas características físicas, realçando suas deformidades distribuídas por rosto, cabeça, costas, pernas, pés, mãos, no caso de Esmeralda a enumeração dos elementos que compõem sua beleza não se contam por si mesmos, mas em meio a uma ação e seu efeito. Se sabemos que Quasímodo é monstruoso, é devido ao eriçado de seus cabelos, à corcova em suas costas, às suas pernas tortas; mas se sabemos que Esmeralda é uma criatura sobrenatural, não é apenas por seu talhe fino, seus olhos negros ou seus braços bem torneados, mas porque vemos tudo isso em movimento; o corcunda é uma figura à qual falta a harmonia necessária à beleza, mas a harmonia que envolve a cigana não se limita à sua figura, revelando-se acima de tudo na dança com que encanta as pessoas ao seu redor. É como se, ao caracterizar seus protagonistas, Hugo encontrasse o limite que já assinalara no prefácio a Cromwell - "o belo não tem senão um tipo; o feio tem mil" (HUGO, 1828, p. XVII) -, sendo necessário enriquecer o tipo de belo que ele descrevia com algo que se situava além da própria figura descrita, os olhares fixos e as bocas abertas que se voltavam para ela.

Mas o contraste entre os dois personagens, ainda que imaginado como uma versão à Walter Scott de $A$ bela e a fera, não é suficiente para explicar a concepção desse romance. De fato, todos os elementos que constituem os personagens dependem (e, de alguma maneira, se constroem em torno) da mistura de estilos e do contraste. Nesse sentido, pode-se notar uma dualidade que marca o destino de cada personagem, a começar pelo próprio Quasímodo, que, ao lado de sua aparência grotesca, mostra os sentimentos mais sublimes. A própria descrição do corcunda, ao mesmo tempo em que ressalta a animalidade desse ser monstruoso, "lambendo suas presas de javali, rugindo como uma besta selvagem”, assinala também o seu caráter composto, ao designá-lo como uma "quimera" (HUGO, 1831, I, p. 142). Por outro lado, a ideia de quimera aproximava-o também da própria catedral, "construção híbrida” (HUGO, 1831, I, p. 242) com a qual ele formava ainda outra unidade dual, como corpo e alma: 
[...] ele era sua alma. A tal ponto que, para aqueles que sabem que Quasímodo existiu, Notre-Dame é hoje deserta, inanimada, morta. Sente-se que há alguma coisa desaparecida. Esse corpo imenso está vazio; é um esqueleto; o espírito o deixou; vê-se o seu lugar, e eis tudo. É como um crânio onde há ainda buracos para os olhos; mas não o olhar (HUGO, 1831, I, p. 337).

Assim, mais do que habitar a catedral, Quasímodo se misturava a ela em uma "harmonia misteriosa", chegando, pouco a pouco, "a se parecer com ela, a se incrustar nela, por assim dizer, a fazer parte integrante dela. Seus ângulos salientes encaixavam-se, com desculpas pela figura, aos ângulos das reentrâncias do edifício" (HUGO, 1831, I, p. 323). É possível supor que a unidade formada entre o sineiro e a catedral ganhava um alcance maior dentro do plano da obra a partir de uma característica básica do personagem, o seu nome.

A narrativa não era decisiva quanto ao motivo pelo qual Claude Frollo batizara com tal nome a criança abandonada dentro da catedral. Talvez fosse para marcar dessa forma o dia em que a encontrou, ou talvez porque o nome caracterizasse a criatura, que "não era mais que um quase" (HUGO, 1831, I, p. 320). Quantos aos motivos de Victor Hugo para dar esse nome ao seu personagem, são ainda mais difíceis de imaginar, mas sabemos que essa decisão foi tomada diante de uma lista de possibilidades bastante distintas. Rabiscados em duas colunas em uma folha de seu manuscrito liam-se, de um lado, os nomes Malenfant, Mardi-Gras, Babylas, Quatre-Vents, Quasimodo e Guerf; de outro, Mamès, Ovide e Ischirion (RELIQUAT, 410v.). A escolha do autor, associando o personagem a uma data do calendário litúrgico, acabaria evocando outros sentidos que contribuíam para compor a rede na qual o significado do romance podia ir se constituindo aos olhos do leitor.

O domingo de Quasímodo, celebrado no primeiro domingo após a Páscoa, recebe seu nome da antífona que introduzia a missa do dia ("quasi modo geniti infantes"), referência à primeira epístola de São Pedro: "como crianças recém-nascidas, desejai ardentemente o leite espiritual e puro, a fim que ele vos faça crescer para a salvação" (I Pe, II, p. 2). ${ }^{2}$ Porém, os versículos seguintes dessa epístola introduziam uma imagem com a qual o apóstolo exortava os fiéis a imitarem Jesus Cristo, "pedra que os arquitetos rejeitaram, e que no entanto se tornou cabeça de ângulo":

${ }^{2}$ As citações bíblicas são traduzidas a partir da edição referenciada ao final, reimpressa a partir de 1827 , em 27 volumes. Trata-se de uma edição em latim e francês de uma tradução preparada no século XVIII pelo abade de Vence, nome que se celebrizou nas edições posteriores. 
Se todavia experimentastes quanto o Senhor é doce, e aproximando-vos dele, como da pedra viva que os homens na verdade rejeitaram, mas que Deus escolheu e honrou, entrai também vós mesmos na estrutura desse edifício, como pedras vivas, para compor uma casa espiritual [...]. Por isso é dito na Escritura: Colocarei em Sião a principal pedra angular, a pedra escolhida e preciosa; e quem tiver fé nessa pedra não será confundido (I Pe, II, p. 3-6).

Assim, incrustando-se na catedral como uma de suas pedras, Quasímodo evocava, por seu nome, a imagem de uma pedra rejeitada, que, no entanto, se mostrava preciosa, reforçando a cadeia de antíteses em que se desdobrava a narrativa; ao mesmo tempo, aprofundava-se o contraste que constituía o personagem, não somente entre o exterior e o interior, entre o grotesco da aparência e o sublime do sentimento, mas ainda entre o sub-humano, besta selvagem, e o sobre-humano, ser divino com que se identificaria por analogia no texto do apóstolo (Pedro ou Pierre, isto é, pedra).

Mas a imagem da pedra não se esgota na figura de Quasímodo, encontrando-se também no nome de sua amada, Esmeralda. Ao contrário de Quasímodo, nesse caso não se trataria de uma pedra rejeitada, mas justamente de uma pedra preciosa, guardando ainda analogia com a figura bíblica; porém, a pedra que dá nome a Esmeralda, de preciosa tem só a aparência:

Ela tirou de seu seio uma espécie de sachê oblongo, que estava pendurado em seu pescoço por uma corrente de grãos de cinamomo. Esse sachê exalava um forte odor de cânfora. Ele era recoberto de seda verde e tinha em seu centro uma grande miçanga verde, imitando a esmeralda (HUGO, 1831, I, p. 218).

Por outro lado, a missanga sem valor que Esmeralda traz ao pescoço é tomada por ela como um amuleto que tem a virtude de permitir-lhe reencontrar a mãe, de quem foi separada quando ainda era um bebê; mas essa virtude do amuleto só teria efeito desde que a moça preservasse a sua própria virtude, guardando a castidade. Dessa maneira, completa-se o jogo de inversões, pois se Esmeralda deve seu nome a uma pedra falsa, essa pedra encerra o significado do que é realmente precioso para a sua felicidade, a pureza e o afeto materno. Ao mesmo tempo, essa busca pela mãe significa também o reencontro com a própria identidade, não mais de Esmeralda, como a nomearam os ciganos, mas de Agnes, seu nome original, que remete à lembrança de uma outra espécie de "amuleto", se assim se pode chamar a devoção católica do agnus-dei, que também se traz ao pescoço, mas que não contém uma pedra, e sim a cera do círio pascal. Assim, do mesmo modo que os nomes Quasímodo e Esmeralda uniam 
os personagens pela imagem da pedra, rejeitada ou preciosa, presente na epístola católica, também os nomes Quasímodo e Agnes os uniam pela origem na celebração da Páscoa, o que refletia, enfim, a origem comum da história de ambos, pois Quasímodo nada mais é que a criança deixada pelos ciganos no lugar de Agnes/Esmeralda e depois abandonada na catedral de Notre Dame.

Outra figura necessária ao entendimento da relação entre o corcunda ea cigana é o arquidiácono Claude Frollo, pai adotivo do primeiro que nutre pela segunda uma paixão proibida. Diferente desses, porém, Frollo internalizará as contradições, expressas já em seu nome, cujo significado mais imediato remete ao adjetivo italiano fròllo, isto é, macio, tenro, podendo ser usado também em sentido figurado ( pasta frolla) para qualificar uma pessoa fraca, sem energia. Ao mesmo tempo, porém, o nome evoca também o verbo francês froler, que significa raspar, friccionar, causar atrito. Assim, o próprio nome do arquidiácono antecipava o conflito vivido pelo personagem, cuja sobriedade e rigidez entram em choque com sua atração por Esmeralda, mas não resistem ao pecado, revelando sua fraqueza.

Destinado desde a infância à vida eclesiástica, Frollo "tinha uma verdadeira febre de adquirir e de entesourar em matéria de ciência. Com dezoito anos, passara por quatro faculdades. Parecia ao jovem que a vida tinha um fim único: saber" (HUGO, 1831, I, p. 314). À medida que o padre se tornava cada vez mais sábio, "como uma consequência natural", tornava-se também mais rígido e triste. Era natural que assim ocorresse devido ao paralelismo existente no desenvolvimento da inteligência, da moral e do caráter, o que, no caso de Frollo, estaria também na origem de seu conflito, pois o desejo insaciável pelo saber antecipava a imagem de sua queda, como um pecado original: "Ele havia, dizia-se, experimentado sucessivamente todas as maçãs da árvore da inteligência e, por fome ou desgosto, ele acabou por morder o fruto proibido" (HUGO, 1831, I, p. 345). Percorrendo todos os degraus da ciência, Frollo levaria sua busca até o limite do conhecimento humano, além do qual se encontraria o objeto único e inalcançável de seu desejo: "fazer ouro é ser Deus; eis a única ciência” (HUGO, 1834, II, p. 17). A ambição de dominar os segredos da alquimia apenas traduzia a mesma imagem do fruto proibido que motivara a queda do primeiro homem diante da tentação da serpente que lhe apresentava o fruto da árvore do conhecimento:

\footnotetext{
Certamente quando comerdes dele não morrereis; e não foi por essa razão que Deus vos fez essa proibição; mas é porque Deus sabe que tão logo houverdes comido desse fruto vossos olhos serão abertos e sereis como deuses, conhecendo o bem e o mal; e ele não quer que vós vos torneis semelhantes a ele (Gn III, p. 4-5).
} 
Em sua busca pelo saber proibido, Frollo se aproximava da fachada da catedral como de um livro que continha um enigma a ser decifrado, um mito, um símbolo, "como o primeiro texto sob o segundo em um palimpsesto" (HUGO, 1831, I, 349). O significado da catedral era, então, muito diverso para o arquidiácono e para Quasímodo; se este parece fazer parte dela como a pedra viva de uma casa espiritual, o outro encontrava ali o desafio da inteligência que tentava a humanidade desde o primeiro pecado, refazendo o caminho da queda original. Assim, o pecado que o imergia na angústia de buscar igualar-se a Deus precedia - se é que não preparava - o conflito interior que o domina quando encontra Esmeralda.

Uma criatura tão bela que Deus a teria preferido à Virgem, e a teria escolhido para sua mãe, e teria querido nascer dela se ela existisse quando ele se fez homem! [...]

Já meio fascinado, tentei me agarrar a qualquer coisa e me deter em minha queda. Em me lembrava dos embustes com que Satã já me havia preparado. A criatura que estava sob meus olhos tinha essa beleza sobre-humana que só pode vir do céu ou do inferno. Não era uma simples moça feita com um pouco de nossa terra e pobremente iluminada no interior pelo vacilante raio de luz de uma alma de mulher. Era uma anjo! Mas das trevas, das chamas, e não da luz (HUGO, 1831, I, p. 309-311).

A catedral e a cigana são, assim, as duas faces de uma mesma paixão que o padre experimenta entre vislumbres do céu e do inferno, da onipotência divina e da fragilidade humana. E será a oscilação entre tais extremos que faz Claude projetar-se em um abismo moral do qual não é capaz de recuar, porque "quando se faz o mal, é preciso fazer todo o mal. Loucura parar no meio do monstruoso! A extremidade do crime tem delírios de gozo" (HUGO, 1831, I, p. 315). O desejo imoderado e vicioso pela ciência e pela cigana se unem na imagem com que Frollo se refere a si mesmo, ao mesmo tempo aranha e mosca. Aranha quando enreda em sua teia a mosca que é Esmeralda, mas também ele próprio mosca, enredado na teia que lhe corta o voo rumo à "ciência, a luz o sol", "ao grande dia da verdade eterna” e o faz ver como era vã sua ambição:

Oh! Insensato! recomeçou sem tirar os olhos da janela. E, quando tu pudesses rompê-la, esta teia formidável, com suas asas de mosquito, tu crês que poderias atingir a luz? Ai de ti! Esse vidro que está mais longe, esse obstáculo que separa todas as filosofias da verdade, como poderá o senhor franqueá-lo? Oh, presunção da ciência! (HUGO, 1831, II, p. 204-205). 
Vemos, assim, que o triângulo amoroso Quasímodo-EsmeraldaFrollo não apenas recriava o tema da bela e da fera, mas procurava, por meio dele, oferecer um modelo do que Hugo acreditava ser o próprio núcleo de uma estética moderna (isto é, romântica), fundada na dualidade e no contraste. Por isso ele desdobrava esse recurso em outras direções, para além do contraste entre o belo e o feio encontrado nas figuras da cigana e do corcunda, exibindo o grotesco e o sublime que remetiam ao contraste entre corpo e alma, exterior e interior, no caso do sineiro, ou o conflito entre céu e terra, divino e humano, fé e ciência, no caso do padre.

Porém, se este é um elemento fundamental à construção dos personagens centrais à história, certamente não basta para explicar o funcionamento do romance, cujo enredo não era devido apenas às ideias de seu autor sobre o moderno. Como vimos no prefácio de Hugo para o Cromwell, o conceito de romantismo se fundamentava primordialmente sobre um senso de historicidade que o definia como uma superação do classicismo. Tratava-se, em sua essência, de uma arte moderna, própria de um novo tempo e de um novo espírito, que se erigia sobre a negação do antigo. Essa estratégia de negação e de oposição, condição mesmo da emergência de um movimento romântico, constituiria também, em termos estéticos, o seu limite, na medida em que a poética clássica (mesmo que para ser negada) se manteria sempre no horizonte dos mais empenhados adeptos da arte moderna. Dessa maneira, seria difícil ignorar o quanto daquela arte que seria própria de um passado morto se converteria em uma herança de que o romantismo usufruía ao mesmo tempo em que a perpetuava.

Na verdade, já se encontrava na poética aristotélica aquilo que viria a ser marcante na tradição do romance romântico (edo romance-folhetim), sempre pródigo em peripécias e reconhecimentos. A partir da presença ou não desses elementos na ação poética, Aristóteles classificava-a em simples ou complexa (ARISTOTE, 1829, p. 51), identificando neles "o que há de mais tocante na tragédia” (ARISTOTE, 1829, p. 33). Em Notre Dame de Paris, longe ainda da revolução operada pelo folhetim, Victor Hugo exibiria um dos mais bem acabados exemplos da migração dessa preceptiva da tragédia clássica para o romance romântico, pois a fábula no sentido aristotélico, "o arranjo das partes de que é composta uma ação poética” (ARISTOTE, 1829, p. 31) - construída por Hugo sobrepunha-se e dominava os personagens, no melhor espírito da tragédia grega: 
Pois a tragédia é a imitação não de homens, mas de suas ações, de sua vida, do que faz a sua felicidade ou infelicidade. Pois a felicidade do homem está na ação. O fim mesmo é a ação, e não a qualidade. A qualidade faz que nós sejamos tais ou tais; mas são as ações que fazem que sejamos felizes ou não. Os poetas trágicos não compõem, então, sua ação para imitar o caráter e os costumes: eles imitam os costumes para produzir a ação; a ação é então o fim da tragédia (ARISTOTE, 1829, p. 31-33).

Na fábula construída por Hugo, as peripécias e reconhecimentos organizavam a ação até o seu desfecho, em que o reconhecimento entre mãe e filha, que se reencontram após anos de separação, é também o momento da separação definitiva das duas, que praticamente se condenam à morte no momento do derradeiro encontro, que retarda a fuga da cigana perseguida pelos soldados. E essa condição em que se dá o reconhecimento final revela outro ponto de contato com a tradição clássica, e igualmente fundamental como elemento do enredo, que é a própria inscrição, gravada em pedra na parede da catedral, que domina todo o romance: anagkh, ou fatalidade ${ }^{3}$.

A ideia de um destino trágico, ao qual os protagonistas não conseguem escapar, fornece o enquadramento geral no qual percebemos o enredo que vai se desenrolando paulatinamente em histórias à primeira vista paralelas. Essa fatalidade, que Claude Frollo vê arrastando-o à perdição, como a mosca que se deixa prender à teia da aranha, é o signo sob o qual se desenrolam todas as histórias que se cruzam nesse espaço dominado pela catedral de Notre Dame. Como um destino que inexoravelmente se cumpre, as duas crianças trocadas pelos ciganos, Quasímodo e Esmeralda, acabam se encontrando; Frollo verá seu protegido e filho adotivo se apaixonar pela mesma mulher que ele deseja; Quasímodo, no afã de proteger Esmeralda, destroça a legião de ciganos que atacavam a catedral para salvá-la da condenação à morte; e a reclusa Gudule, a mãe enlouquecida ao ter sua filha roubada pelos ciganos, tenta prender Esmeralda para entregar aos soldados, sem saber que é a mesma criança perdida. E para todos eles reserva-se o destino último, fatalidade inescapável que os subjuga, a morte.

3 O Reliquat de Notre Dame de Paris inclui a página arrancada de um dicionário grego-francês, na qual consta o verbete para anagkh definido como "necessidade; constrangimento: lei fatal, obrigação imperiosa; destino; morte; calamidade"; o verbete registra ainda que, sobretudo no plural, a palavra pode significar "suplício, tortura" (RELIQUAT, 454V.). 
Em 1830, as turbulentas representações do Hernani dariam a Victor Hugo uma notoriedade quase mítica, associada ao tom revolucionário que ecoava de um prefácio bem menos prolixo que o de Cromwell. Dessa vez, a evolução da história da civilização cedia lugar a uma retórica que realçava a ruptura representada pelo romantismo, cujo marco se deslocava do advento do cristianismo para a Revolução Francesa:

O romantismo, tantas vezes mal definido, não é, no fim das contas, e está aí sua definição real, senão o liberalismo em literatura. A liberdade na arte, a liberdade na sociedade, eis o duplo fim ao qual devem tender num mesmo passo todos os espíritos conseqüentes e lógicos [...]. Este princípio é o do século, e prevalecerá. Esses ultras de toda espécie, clássicos ou monarquistas, terão de se ajudar muito para refazer o antigo regime com todas as peças, sociedade e literatura; cada progresso do país, cada desenvolvimento das inteligências, cada passo da liberdade fará desmanchar tudo que eles construírem. E, definitivamente, seus esforços de reação terão sido úteis. Em uma revolução, todo movimento faz avançar. [...] Ora, após tantas grandes coisas que nossos pais fizeram, e que nós vimos, eis-nos saídos da velha forma social; como não sairíamos da velha forma poética? A um povo novo, arte nova (HUGO, 1830, p. II-III).

Porém, a mesma notoriedade que envolveria a figura de Hugo numa aura de mudança, ruptura, revolução, acabaria por encobrir aquela que talvez tenha sido a sua contribuição mais relevante para uma renovação estética do romance, e que se sustentava sobre uma sofisticada convivência de elementos da tradição e da inovação, do classicismo e do romantismo. Afinal, por mais que se empenhasse em afirmar a arte moderna, em seus dramas Hugo encontrava limites formais que não pretendia ultrapassar, como se via claramente em sua defesa do verso, que ele definia como "a forma ótica do pensamento. Eis porque ele convém, sobretudo, à perspectiva cênica. Feito de certa maneira, ele comunica seu relevo a coisas que, sem ele, passariam por insignificantes evulgares" (HUGO, 1828, p. XLV). O romance, ao contrário, constituía uma forma em si mesma moderna, cabendo ao artista romântico mostrar nela não somente a sua capacidade de subversão, mas de invenção e adaptação de regras, de fato inexistentes.

Assim, o combate travado contra os preceitos do teatro clássico ao longo da década de 1820 revelava-se na obra de Victor Hugo em sua significação complexa e até certo ponto contraditória: por um lado, impondo-se como missão necessária à afirmação de uma identidade romântica, constituía ao mesmo tempo um limite à nova estética; por outro lado, na medida em que migrava dos debates teatrais, fornecia um novo paradigma a partir do qual pensar o romance, caracterizado pela hibridação de categorias (como 
"romance dramático"), tornando possível sua atualização por meio de soluções formais que combinavam a mistura de estilos, do grotesco e do sublime, na construção dos personagens e o aproveitamento de definições próprias da poética clássica na construção do enredo.

Ao formular o sentido histórico do romantismo, o prefácio do Cromwell já afirmara a necessidade da evolução artística, limitando o classicismo a um passado esgotado, pela necessidade de imitação, em suas possibilidades criativas; afinal, "a Antiguidade não teria feito $A$ Bela e a Fera” (HUGO, 1828, p. XIX). Ao fazer sua própria versão para $A$ bela e a fera, Victor Hugo voltava sobre seus próprios passos e mostrava, por meio do romance, o verdadeiro salto do romantismo, não simplesmente romper com o passado, mas reinventá-lo.

\section{REFERÊNCIAS BIBLIOGRÁFICAS}

ARISTOTE. Poetique d'Aristote. Trad. et notes de l'Abbé Batteux. Paris: Imprimerie d'Auguste Delalain, 1829.

AVANT-PROPOS. In: La muse française. T. 1,1823.

HUGO, Victor. Cromwell. Paris: Ambroise Dupont \& Cie., 1828.

HUGO, Victor. Hernani, ou l'honneur castillanne. Paris: Mame et Delaunay-Vallée Libraires, 1830.

HUGO, Victor. Notre Dame de Paris. 3 v. Bruxelles: Louis Hauman et Compe Libraires, 1831 .

HUGO, Victor. Notre Dame de Paris. 3 v. Bruxelles: Louis Hauman et Comp ${ }^{\mathrm{e}}$ Libraires, 1834 .

HUGO, Victor. Quentin Durward ou l'écossais à la cour de Louis XI. In: La muse française. T. 1,1823 .

La Sainte Bible de Vence, en latin et en français. T. II. Paris: Mame et Delaunay-Vallée Libraires; Méquignon et Comp. Libraires, 1827.

La Sainte Bible de Vence, en latin et en français. T. XXIII. Paris: Méquignon-Havard, Libraire, 1830.

Reliquat de Notre Dame de Paris. Bibliotèque Nationale de France, NAF, 13378.

SÉCHÉ, Léon. Le cénacle de la Muse française. 1823-1827 (Documents inédits). Paris: Mercure de France, 1909.

STENDHAL, M. de. Racine et Shakespeare. Paris: Bossange; Delaunay; Mongie, 1823. 